\title{
Cesta Romana Bergera
}

\author{
(9. 8. $1930-22.12 .2020)$
}

\section{Lucia Jakubisová}

„Étos je funkciou kreativity. Kreativita je funkciou kultúrnosti.

Tvorivost', kultúrnost', mravnost' sú, ako sa zdá, aspekty toho istého - univerzálnej Lásky, Princípu života, negentropie."

(Roman Berger)

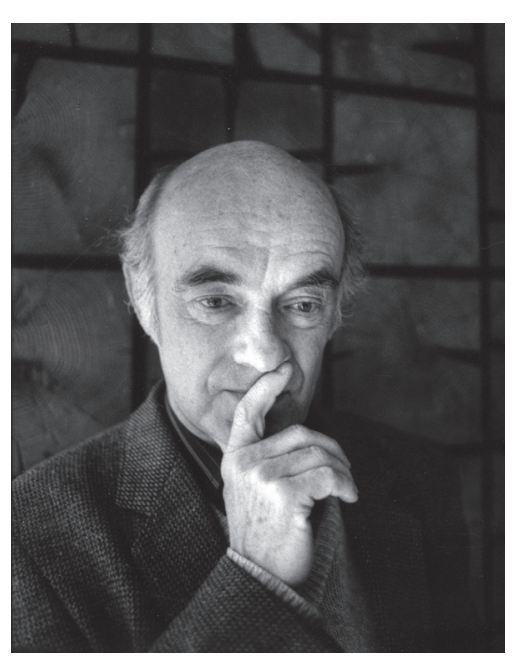

Roman Berger

Foto: Milan David, Archív Hudobného centra
Hudobný skladatel', teoretik a myslitel' Roman Berger sa stal výraznou osobnost'ou kultúrneho prostredia na Slovensku a jeho nezamenitelný skladatel'ský odkaz pozná široká umelecká obec. Opustil nás 22. decembra 2020 vo veku významného životného jubilea 90 rokov.

Celoživotné skladatel'ské dielo rodáka z pol'ského Cieszyna Romana Bergera je svedectvom viery $v$ nevyhnutnost' neustáleho hl'adania „Pravdy" a výpoved’ou osobnej životnej cesty, poznačenej vojnou, migráciou, bytím, spiritualitou i ludskými stigmami. Hudba a slovo sa stali osobnými prostriedkami vymedzovania sa voči totalite $v$ akejkolvek podobe i príležitostou pomenovat' vlastný vztah k hudbe - ako jazykom tej vnútornej i vonkajšej slobody.

Bergerovo myslenie o hudbe zakotvené vo filozofickom prostredí bolo stimulátorom k tvorivému kompozičnému procesu a k pisatel'skej činnosti. Svedčí o tom obsažné vydanie Bergerových esejí a zamyslení v publikáciách Hudba a pravda. „... tak takto nesmieš mysliet!...." (Európsky kultúrny klub na Slovensku, 1997), Dráma hudby. Prolegomena k politickej muzikológii (Hudobné centrum, 2000), Zasada twórczości (Akademia 
Muzyczna im. Karola Szymanowskiego, 2005) a Cesta s hudbou. Od Palacha po Obamu - a po Štefánika (Hudobné centrum, 2012). Spoločným menovatel'om uvedených knižných výstupov je averzia voči utilitaristickému životu a túžba navrátit’ étos do kultúry jednotlivca i spoločnosti. Étos sa stal centrom jeho úvah, v umení hladal pravdu poukázaním na kultiváciu ducha a autenticitu tvorby. Medzi autentické umenie zarad’oval aj avantgardné umenie. Spolu s Iljom Zeljenkom, Ivanom Paríkom, Petrom Kolmanom a d’alšími patril ku skladatel'skej generácii, ktorá výrazne profilovala scénu slovenskej hudobnej avantgardy najmä počas 60 . rokov 20 . storočia.

Stretnutie s hudbou sa v začiatkoch odohrávalo v humanisticky zmýšlajúcom rodinnom prostredí, formovanom povolaním otca-evanjelického farára. Ďalšie hudobné skúsenosti už rozvíjal na Vysokej hudobnej škole v Katoviciach v rokoch 1949 až 1952 v klavírnej triede u Marty Gabryś-Furmanikowej a upevňoval ich tiež v podobe návštev prednášok harmónie, hry na klavíri a organe u Jana Gawlasa. Po vynútenej emigrácii do Bratislavy v roku 1952 sa prihlásil na VŠMU a zdokonal'oval sa v klavírnej interpretácii u Frica Kafendu a Štefana Németha-Šamorínskeho. Po absolútoriu v roku 1956 sa až do roku 1965 pedagogicky angažoval na Štátnom konzervatóriu v Bratislave. Už v tomto období vznikali prvé miniatúrne kompozície venované práve sólovému klavíru, napríklad Fantasia quasi una sonata (1955), i klavírne cykly Pät'vel'mi krátkych skladieb (1959), Pät'štúdií (1959 - 1960) a Malá suita (1961), vydané v Slovenskom hudobnom fonde pod názvom Invencie ( 3 × 5 miniatúr). Tieto diela mu mohli zabezpečit' štúdium v pol'ských Katoviciach u Bolesława Woytowicza. To sa však z dôvodu nesúhlasu štátnych úradov nezrealizovalo.

Namiesto toho nastúpil na VŠMU, kde začal svoje štúdium kompozície v triede Dezidera Kardoša, vtedajšieho predsedu Zväzu slovenských skladatelov. Absolvoval skladbou Transformácie s podtitulom „Štyri skladby pre vel'ký orchester“ (1964 - 1965), v ktorej uplatnil nový zvukový ideál - elektronickú manipuláciu so zvukom. Po štúdiu kompozície pôsobil ako pracovník Zvukového štúdia Československej televízie a skomponoval tu hudbu k mnohým dokumentárnym filmom. V období politického uvolinenia sa krátkodobo stal tajomníkom skladatel'skej sekcie Zväzu slovenských skladatel'ov. Od roku 1969 do 1971 externe vyučoval na Katedre teórie Hudobnej fakulty VŠMU súčasnú hudbu. V období 1972 až 1977 mu bola zakázaná umelecká činnost'. Počas 70. rokov začal spolupracovat’ s výskumným tímom Ivana Mačáka v oblasti etnomuzikológie. V rokoch 1980 až 1989 sa jeho pracoviskom stal Umenovedný ústav SAV v Bratislave. K pedagogickej činnosti sa vrátil v rokoch 1982 až 1984, ked'ako externý pedagóg vyučoval elektroakustickú kompozíciu na Katedre skladby a dirigovania na VŠMU.

Bergerove mimohudobné aktivity sa spájali s matematikom Belom Riečanom a organizovaním seminárov Matematika a hudba. Berger inklinoval k mnohým inšpiratívnym osobnostiam z mimohudobnej oblasti - filozofom, teológom, psychológom, vedcom (napríklad Karl Jaspers, Paul Tillich, Martin Buber, Zbigniew Herbert, Pierre Teilhard de Chardin, Erwin Schrödinger, Norbert Wiener, Carl Friedrich von Weizsäcker, Douglas Hofstadter, sv. Ján Pavol II. a mnohí d’alší). Ich argumentačný aparát rozvíjal aj prostredníctvom vlastných ideí. Koexistencia hudby a slova sa pre skladatela Romana Bergera stala prostriedkom vyjadrenia náreku, protestu i nádeje. V meditatívnom charaktere zhudobňoval skrytý zmysel vecí a rozjímal nad prežitými udalost’ami. Skladby ako triptych Konvergencie I - III pre sólové sláčikové nástroje (1968 - 1974), organový cyklus Exodus (1981 - 1997), d’alej Adagio pre Jana Branného (1987) i Adagio č. 2 „Po- 
kánie" (1988 - 1989) pre husle a klavír či klavírne Soft November Music (1989) sú len výberom z komorných opusov, ktoré spájajú Bergerov exaktný spôsob hudobného uvažovania a duchovný kompozičný podpis vychádzajúci z filozofických ideí.

Po novembri 1989 Roman Berger spolu s českými skladatelmi Marekom Kopelentom a Aloisom Piňosom prispel k oživeniu činnosti československej sekcie Medzinárodnej spoločnosti pre súčasnú hudbu (ISCM). Bol členom viacerých výborov a porôt. Spomeňme aspoň Medzinárodnú skladatel'skú sút’až Henryka Wienawského v Poznani a Medzinárodnú skladatel'skú sútaž Witolda Lutosławského vo Varšave, d’alej čestné členstvo vo Zväze pol'ských skladatel’ov, členstvo v Skupine pre reformu umeleckého školstva pri Ministerstve kultúry i Poradného zboru Ministerstva kultúry a i.

Etické a humanistické poslanie umenia formoval v prípravnom výbore Medzinárodného festivalu súčasnej hudby so symbolickým názvom Melos-Étos, autorom ktorého bol práve sám Berger. Na členstvo vo Festivalovom výbore však v roku 1999 rezignoval a na vlastnú písomnú žiadost' skladatel’a na festivale nezaznela ani komorná skladba Requiem da camera pre husle, violončelo a klavír (1998). Rozhodnutie sa uskutočnilo v čase vojenského zásahu NATO v bývalej Juhoslávii. „[...] predstava, že by sa s mojím súhlasom mala hrat'moja hudba v dobe, ked',za humnami' sa koná diabolský, festival skazy' - vyháňania a vraždenia nevinných ludí, bombardovania a nivočenia krajiny atd.' - je pre mňa absurdná."2 Základným kritériom Bergerových umeleckých aktivít totiž bola vlastná celoživotne deklarovaná téza postavená na humánnom postoji, t. j. smerovat' človeka k absolútnym hodnotám a univerzálnym princípom, ku kultúre sensu stricto a k základnej kategórii kultúry Sacrum. „Kultúra nie je automaticky tam, kde prosperujú divadlá, filharmónie, vydavatel'stvá, galérie, vedecké ústavy či dokonca školstvo. Duchovná kultúra je tam, kde sa prejavuje kultúrnost'v správaní a myslení, kde spontánne dominuje úcta k životu, človeku, poznaniu, tvorbe. Kde je samozrejmostou empatia a solidarita, zmysel pre spravodlivost' a zodpovednost', schopnost' počúvat' toho druhého a viest' dialóg - ,spoločne sa približovat' k pravde "." ${ }^{3}$

Za skladatel'skú tvorbu a inšpirujúce práce z oblasti filozofie a hudobnej teórie získal v roku 2012 Cenu Zväzu pol'ských skladatel'ov. Tiež sa stal držitel’om Ceny Jána Levoslava Bellu (2010), Výročnej ceny Ministra kultúry a národného dedičstva Pol'skej republiky za vynikajúce výsledky v oblasti hudby (2007), Vel'kej ceny SOZA za celoživotný prínos v oblasti hudby udelenej za rok 1999. Ďalej získal Cenu kritiky za rok 1997 za skladatel'ské, filozofické a umenovedné dielo a mnohé iné. V roku 1988 sa stal nositelom Herderovej ceny, udel'ovanej Viedenskou univerzitou výrazným osobnostiam, ktoré prispeli k zachovaniu a rozvíjaniu európskeho kultúrneho dedičstva.

Memento Romana Bergera, zaznamenávajúce i tie najtragickejšie stigmy ludstva a odrážajúce sa v dielach Korczak in memoriam (2000), Post scriptum (2004), Missa pro nobis (2010), Tenebrae (2011), Spevy Douvy (2012), je posolstvom vyzývajúcim nanovo objavit' ludskost', ktorá je klúčom k dialógu a k mieru. Berger nezatváral oči pred životom ani pred smrtou a $v$ mnohých prípadoch sa $s$ touto ontologickou otázkou vyrovnával vo svojej profesijnej činnosti, najmä v jej morálnych aspektoch, miestami až radikálnym spôsobom. Usiloval sa predíst' vnútornej (duchovnej) smrti a denne viedol osobný boj medzi vnútorným a vonkajším človekom, ktorý sám definoval ako zápas medzi anjelom a beštiou, medzi bytost’ou prirodzenou (vita activa) a bytost'ou nadprirodzenou (vita contemplativa). Na záver slovami samotného Romana Bergera: 
"Hovorí sa, že hudba je ,umenie v čase.' Hodiny Vesmíru tikajú od nepamäti. Z toho tajomného tikania sa vynoril čas živých stvorení, čas ludskej histórie a napokon čas každého z nás. Prežívaný ludský čas, o ktorom vieme, že ,nevieme dňa ani hodiny. Že každé naše predsavzatie - ak ho vôbec budeme môct'/smiet' dokončit', môže byt' tým posledným. Akýmsi epilógom nášho nepatrného príbehu. " ${ }^{4}$ Roman Berger svoj príbeh tu na zemi zavŕšil, avšak jeho dielo a odkaz zostávajú medzi nami nad’alej živé...

\section{POZNÁMKY}

1 BERGER, Roman:„Nežná revolúcia“ a hudba (1990). In: Cesta s hudbou. Od Palacha po Obamu - a po Štefánika. Výber textov z rokov 1969 - 2009. Bratislava: Hudobné centrum, 2012, s. 70.

2 BERGER, Roman: List výboru festivalu Melos-Étos (1999). In: Dráma hudby. Prolegomena k politickej muzikológii. Výber textov z rokov 1990 - 1999. Bratislava: Hudobné centrum, 2000, s. $347-348$.
3 BERGER, Roman: Čo by na to povedal L'udovít Štúr? (2006). In: Cesta s hudbou. Od Palacha po Obamu - a po Štefánika. Výber textov z rokov 1969 - 2009. Bratislava: Hudobné centrum, 2012, s. 371.

4 BERGER, Roman: Na Zelený štvrtok 2010. Archív Hudobného centra. 